
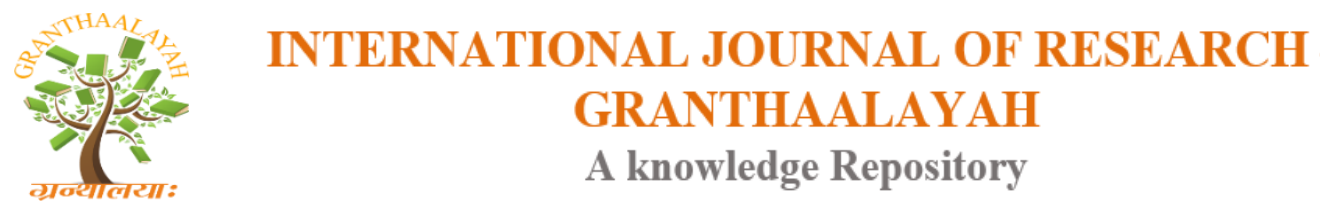

Social

\title{
FARMERS' PERCEPTION OF POVERTY AND WELFARE IN BOKI LOCAL GOVERNMENT AREA OF CROSS RIVER STATE, NIGERIA
}

\author{
Rosemary I. Eneji ${ }^{1}$, Attah Frank Mbeh ${ }^{2}$ \\ 1,2 Department of Sociology, University of Calabar, Nigeria
}

\begin{abstract}
The worsening state of poverty among rural farmers in Nigeria's Cross River State has attracted great concern from government and its agencies but farmers' perception of poverty and welfare is little understood. In this study, it was determined whether and how the social variables of income, healthcare and education affect farmers' perception of poverty and welfare in Boki Local government area. Primary data were derived from one hundred (100) respondents, randomly drawn from the study area using standard questionnaires and analysed using the chi-square technique. There was a significant direct relationship between income level, health care, education and nutrition on one hand and welfare of farmers on the other. Evidence from this field study strongly suggests that poverty alleviation programmes and infrastructural projects should be extended to rural areas for improved welfare and livelihood. However, farmers do not necessarily perceive poverty based only on the variables studied.
\end{abstract}

Keywords: Farmers; Poverty; Welfare; Boki; Nigeria.

Cite This Article: Rosemary I. Eneji, and Attah Frank Mbeh. (2018). “FARMERS' PERCEPTION OF POVERTY AND WELFARE IN BOKI LOCAL GOVERNMENT AREA OF CROSS RIVER STATE, NIGERIA." International Journal of Research - Granthaalayah, 6(7), 151-158. https://doi.org/10.29121/granthaalayah.v6.i7.2018.1293.

\section{Introduction}

Agriculture is a very important sector of the Nigeria economy, employing about $70 \%$ of the total active labour force and contributing about $42 \%$ of gross domestic product (GDP) (Ajibefun, 2007). Nigerian farmers have been described as very poor with low income, especially in the rural areas where they face low production (Ijere, 2004). For this reason, they are unable to provide enough funds to expand their production activities.

Welfare, though not observable, could be said to represent the people's standard of living. In theory, a household's consumption expenditure on food and education is used as proxy for welfare indicators (Quartey, 2005). Many households in Nigeria, especially in rural areas, cannot afford necessary farm inputs or implements such as fertilizers, pesticides and improved seeds, which 
bring about increase in productivity and hence, an increase in household income which will proactively affect the socio-economic well-being of household positively (Ukoha, 2007).

In 2004, Nigeria's relative poverty measurement was $54.4 \%$ but increased to $69 \%$ in 2010 . The South-West geo-political zone recorded the lowest poverty rate $(59.1 \%)$ among the six geopolitical zones in Nigeria. It however remains a paradox that Nigeria's economy is growing, yet the proportion of Nigerians living in poverty seems to be increasing every year. According to some reports (e.g., Ikwechegh, 2009; Ekpo, 2007; Aluko, 2008), majority of the rural poor are small scale farmers and the poverty gap is ever becoming wider which calls for corrective action. Thus, targeting of rural farming households seems imperative in alleviating poverty in Nigeria.

The specific objective of this study was to ascertain the socio-economic characteristics of the farming household and determinants of poverty among the rural farmers in Boki Local Government Area of Cross River State.

\section{Materials and Methods}

\section{Study Area}

The research was carried out in Boki Local Government Area of Cross River State, Nigeria. The area is mostly agrarian, characterized by seasonal cycles of poverty and comprised fourteen major communities, including Iso-Bendeghe, Basan-Osokom, Nsadop, Abo, Okundi, Iruan, Bateriko, Bumaji, Orimekpang, Wula, Buadior, Natamante and Kakwagom. Boki bears a national and international reputation for being a major commercial centre where forest and internationally quoted agricultural commodities such as cocoa, coffee, timber, palm products, etc. are sourced and supplied for international consumption.

\section{Population of the Study and Sampling}

A stratified random sampling was used to select five (5) communities out of the fourteen in the Local Government Area, from which one hundred and ten (110) respondents were again randomly selected for study (Table 1).

Table 1: Communities and number of respondents used for the Study

\begin{tabular}{|l|l|l|}
\hline S/N & Communities & No of Respondents \\
\hline 1. & Nsodop Abo & 22 \\
\hline 2. & Bendeghe & 22 \\
\hline 3. & Bumaji & 22 \\
\hline 4. & Iruan & 22 \\
\hline 5. & Kakwagom & 22 \\
\hline & Total & 110 \\
\hline
\end{tabular}

A questionnaire titled "Farmers Opinion of Poverty" (FOQ) was developed in two sections. Section "A" sought information on personal and demographic issues such as age, sex, educational qualification and status; section "B" was a twenty (20) item product Likert type questionnaire items demanding varying levels of agreement or disagreement: strongly agreed (SA), agree (A), disagree (D) and strongly disagree (SD). Each of the instruments required the respondent to indicate the extent the statement appeals to him/her. 


\section{Data collection}

Copies of the questionnaire were administered to the selected respondents, who were informed of the exercise and the importance of giving objective response to the items. The farmers were also told to be honest and that true response to the item will help identify the problem of their welfare and poverty level. After the exercise one hundred (100) questionnaires were returned by the farmers.

\section{Data analysis}

Data were summarized into simple averages/percentages and the chi-square analysis was performed to determine the degree of association between farmers' perception of issues of education, health care, nutrition, and level of poverty.

\section{Results and Discussion}

\section{Background of Respondents}

Information on the sex, marital status, age and education of the respondents is presented in Table 2. The males constituted $70 \%$ and the females $30 \%$ of the study population; thus the respondents were dominated by men. Table 2 also shows the marital status of the respondents - $65 \%$ were married, $33 \%$ were single and $2 \%$ were divorced. The age distribution of the respondents showed that most (35\%) of them were relatively young, being 31-40years followed by 29\% aged 21-30 years, 27\% 41-50 years and 9\% 51 years and above.

Table 2: Background information on respondents

\begin{tabular}{|l|l|l|}
\hline Item & Number & Percentage \\
\hline Sex & & \\
\hline Male & 70 & $70 \%$ \\
\hline Female & 30 & $30 \%$ \\
\hline Total & 100 & $100 \%$ \\
\hline Marital status & & \\
\hline Married & 65 & $65 \%$ \\
\hline Single & 33 & $33 \%$ \\
\hline Divorced & 2 & $2 \%$ \\
\hline Total & 100 & $100 \%$ \\
\hline Age & & \\
\hline $21-30$ years & 29 & $29 \%$ \\
\hline $31-40$ years & 35 & $35 \%$ \\
\hline $41-50$ years & 27 & $27 \%$ \\
\hline 51 years and above & 9 & $9 \%$ \\
\hline Total & 100 & $100 \%$ \\
\hline Education & & \\
\hline SSCE & 48 & $48 \%$ \\
\hline Diploma & 13 & $13 \%$ \\
\hline NCE & 22 & $22 \%$ \\
\hline B.Sc/B.Ed & 2 & $2 \%$ \\
\hline Others & 15 & $15 \%$ \\
\hline Total & 100 & $100 \%$ \\
\hline
\end{tabular}


The respondents with Senior Secondary education constituted $48 \%$ which was the highest number, those with diplomas were $13 \%$, NCE $22 \%$, B.Sc/B.Ed or any equivalent degree $2 \%$ and other qualifications 5\%. Thus, respondents with SSCE were more than other certificate holders.

\section{Relationship between Farmers' Opinion on Income, Health Care, Education and Nutrition Versus Level of Poverty}

Table 3 shows the farmers perception of the link between their income situation and their poverty or livelihood. The Chi-square summary below the table shows a significant inverse relationship between income level and welfare of farmers in the communities. George (2008) reported that the lack of income among farmers in rural areas was an obvious limitation not only to their effort to escape poverty but also to the state of agricultural productivity in Nigeria. Since they do not even have enough money to feed or buy improved farm inputs, it is usually difficult for them to expand their farms beyond the subsistent level. According to Udo (2009), the low income of farmers was aggravated by the refusal of Banks to grant them loans since they have no tangible collateral.

Table 3: Farmers' perception of the link between their income situation and poverty and the chisquare summary

\begin{tabular}{|c|c|c|c|c|c|}
\hline $\mathbf{S} / \mathbf{N}$ & Questionnaire Items & SA & A & D & SD \\
\hline 1. & Our basic source of income is through our farm product. & & & & \\
\hline 2. & We farm for subsistent purpose rather than for commercial use. & & & & \\
\hline 3. & We lack adequate market where we can easily sell our farm product. & & & & \\
\hline 4. & $\begin{array}{l}\text { Our farm product cannot earn us enough income to carter for our } \\
\text { basic needs. }\end{array}$ & & & & \\
\hline 5. & Based on our present condition of life we are poverty ridden. & & & & \\
\hline & Total & 255 & 120 & 60 & 65 \\
\hline
\end{tabular}

$\mathrm{Df}=98$

\begin{tabular}{|l|l|l|}
\hline Variable & Observed & Expected \\
\hline Strongly Agreed & 255 & 125 \\
\hline Agreed & 120 & 125 \\
\hline Disagreed & 60 & 125 \\
\hline Strongly Disagreed & 65 & 125 \\
\hline Total & 500 & 500 \\
\hline
\end{tabular}

Tabulated value $=9.88$

Level of significance $=0.05$

Computed value $=167.13$

Our data also showed a significant relationship between health care and the welfare of farmers in the study area. The five questions that were asked under this sub-variable (poor health care) and their level of responses are shown in Table 4. A report by Iyewarun (2006) showed that the lack of adequate health facilities in rural areas greatly accounted for the prevalent high mortality rate in such areas. Farmers mostly get sick after an intensive and stressful farm work, especially during the peak farming season. Without drugs or health clinics or even money for treatment, they experience a high rate of destitution or make do with traditional herbs which tend to be less 
effective. Eliot (2009) reported that the poor health care of farmers affects them negatively as they were not able to cope with farm drudgery.

Table 4: Farmers' perception of the link between health care and their welfare and the chi-square summary

\begin{tabular}{|l|l|l|l|l|l|}
\hline S/N & Questionnaire Items & SA & A & D & SD \\
\hline 6. & $\begin{array}{l}\text { We farmers are prone to sickness because of our hard labour in the } \\
\text { farm. }\end{array}$ & 75 & 15 & 8 & 2 \\
\hline 7. & Standard health care facilities are not located in our vicinity. & 47 & 28 & 15 & 10 \\
\hline 8. & We mostly rely on traditional medicine and care when we are sick. & 53 & 33 & 7 & 7 \\
\hline 9. & $\begin{array}{l}\text { We mostly travel to a far distance for medical care when we are on } \\
\text { critical health issues. }\end{array}$ & 41 & 29 & 19 & 11 \\
\hline 10. & $\begin{array}{l}\text { Most of us farmers and our siblings die as a result of poor health } \\
\text { care and how expensive it is. }\end{array}$ & 69 & 23 & 3 & 5 \\
\hline & Total & 285 & 125 & 52 & 35 \\
\hline
\end{tabular}

Chi-square summary

$\mathrm{X}^{2}=$ Chi-square

\begin{tabular}{|l|l|l|}
\hline Variable & Observed & Expected \\
\hline Strongly Agreed & 285 & 125 \\
\hline Agreed & 128 & 125 \\
\hline Disagreed & 52 & 125 \\
\hline Strongly Disagreed & 35 & 125 \\
\hline Total & 500 & 500 \\
\hline
\end{tabular}

Df $=98$

Tabulated value $=9.88$

Level of significance $=0.05$

Computed value $=111.936$

There was also a significant relationship between level of education and welfare of the farmers. The five questions under the sub-variable (poor education) and their level of responses are in Table 5. Ndu (2002) considered the illiteracy rate of farmers to be a key factor that has defied governmental and non-governmental organization's effort to enhance the farming system of farmers. The high rate of illiteracy among farmers in particular and rural dwellers in general has accounted for the low agricultural productivity. This is basically because most farmers are still holding unto the traditional method of farming (Ushie, 2005) without realising that mechanized farming is highly productive and less stressful. And since no effort is made to create awareness among the farmers and educate them on modern techniques, they are being left to wallow in the degenerating state of illiteracy.

Table 5: Farmers' perception of the link between education and welfare together with the chisquare summary

\begin{tabular}{|l|l|l|l|l|l|}
\hline S/N & Questionnaire Items & SA & A & D & SD \\
\hline 11. & $\begin{array}{l}\text { We lack knowledge about the processes involve in mechanize } \\
\text { farming. }\end{array}$ & 35 & 27 & 28 & 20 \\
\hline
\end{tabular}




\begin{tabular}{|c|l|l|l|l|l|}
\hline 12. & $\begin{array}{l}\text { There are no adequate schools with sound learning facilities in my } \\
\text { area. }\end{array}$ & 54 & 5 & 9 \\
\hline 13. & $\begin{array}{l}\text { There is no enlightenment programmes organized to enlighten } \\
\text { farmers about mechanize farming. }\end{array}$ & 51 & 21 & 15 & 13 \\
\hline 14. & $\begin{array}{l}\text { Our farming system is based on the limited knowledge we have } \\
\text { about farming. }\end{array}$ & 50 & 30 & 10 & 10 \\
\hline 15. & $\begin{array}{l}\text { Going to school outside our rural areas is too expensive for we } \\
\text { farmers. }\end{array}$ & 37 & 21 & 18 & 24 \\
\hline & Total & 227 & 131 & 76 & 76 \\
\hline
\end{tabular}

Source: Field Survey 2015

$\mathrm{X}^{2}=$ Chi-square summary

Df $=98$

\begin{tabular}{|l|l|l|}
\hline Variable & Observed & Expected \\
\hline Strongly Agreed & 227 & 125 \\
\hline Agreed & 131 & 125 \\
\hline Disagreed & 76 & 125 \\
\hline Strongly Disagreed & 76 & 125 \\
\hline Total & 500 & 500 \\
\hline
\end{tabular}

Tabulated value $=9.88$

Level of significance $=0.05$

Computed value $=121.936$

The result of the analysis of the relationship between feeding and poverty (Table 6) is similar with the others above. This result is consistent with that of Akintunde (2010) that lack of good food and access to safe water was a major cause of the high rate of sickness among rural dwellers in Nigeria. Since most of them only eat diets that are poor in nutrients and drink unclean water from natural rivers and streams, they experience regular sickness. Worst still, after contacting water-borne disease, they lack the money for good medical treatment and end up dying at a very young age. Edem (2008) stated that rural farmers who are the producers of most foods are the ones that are poorly fed in Nigeria.

Table 6: Farmers' perception of the link between nutrition and welfare together with the chisquare summary

\begin{tabular}{|l|l|l|l|l|l|}
\hline S/N & Questionnaire Items & SA & A & D & SD \\
\hline 16. & Our food is basically from our farm product. & 72 & 15 & 8 & 5 \\
\hline 17. & $\begin{array}{l}\text { Purchasing other types of food like tea, rice, chicken, meat etc, } \\
\text { seem to be too expensive and a waste of money. }\end{array}$ & 32 & 15 & 23 & 30 \\
\hline 18. & $\begin{array}{l}\text { We farmers mostly eat what we see and have and not base on it } \\
\text { nutritious content. }\end{array}$ & 51 & 27 & 12 & 10 \\
\hline 19. & We mostly fall sick because of our poor feeding habit. & 36 & 40 & 14 & 10 \\
\hline 20. & Inspite of the fact that we are farmers we are mostly poorly fed. & 67 & 10 & 9 & 14 \\
\hline & Total & 258 & 107 & 66 & 69 \\
\hline
\end{tabular}


$\mathrm{X}^{2}=$ Chi-square summary

$\mathrm{Df}=98$

\begin{tabular}{|l|l|l|}
\hline Variable & Observed & Expected \\
\hline Strongly Agreed & 258 & 125 \\
\hline Agreed & 107 & 125 \\
\hline Disagreed & 66 & 125 \\
\hline Strongly Disagreed & 69 & 125 \\
\hline Total & 500 & 500 \\
\hline
\end{tabular}

Tabulated value $=9.88$

Level of significance $=0.05$

Computed value $=197.1$

\section{Conclusions and Recommendations}

There is a significant relationship between income level, education, health care and nutrition on one hand and poverty and farmers' welfare on the other. Low income and education as well as poor health care and nutrition have greatly contributed for the poor state of farmers in Boki local government area, trapping them in a vicious cycle of poverty.

Both the government and non-governmental organizations should ensure that farmers are provided with all the necessary support that will facilitate their farming activities which will in turn boost their welfare and eliminate the degenerating state of poverty among them. Efforts at poverty alleviation should focus on the key areas of health care, nutrition and education of the rural populace.

\section{References}

[1] Acosta, P. (2008). "ONE THE WEED FOR AN OPERATIONAL SPECIFICATION OF POVERTY IN THE NIGERIAN ECONOMY". Poverty in Nigeria. Proceedings of The 2008 Annual Conference of the Nigeria Economics Society.

[2] Ajebetun, H. (2007). "SEASONAL DIMENSION TO RURAL POVERTY". Frances Pinter Publishers Ltd.

[3] Aluko, K. (2003). "POVERTY: ITS REMEDIES", IN POVERTY IN NIGERIA". The Nigerian Economic Society. Ibadan: Crosy Production.

[4] Banku, O. (2002). "THE NIGERIAN ECONOMIC CRISIS: CAUSE AND SOLUTION". Zaria: Gaskiya Corporation Limited.

[5] Ben, J. (2006). "ECONOMIC OF WEST AFRICA". London: Macmillan Press Ltd.

[6] Chambers, R. (2005). "POVERTY AND LIVELIHOODS: WHOSE REALITY REALLY COUNTS?" A Policy Paper Commission by UNDP for World Summit for Social Development (March).

[7] Edem, B. (2008). "RURAL DEVELOPMENT AND THE PERSISTENCE OF POVERTY". University of Uyo Inaugural Lectures Series No. 1.

[8] Eliot, U. (2009). "POVERTY ALLEVIATION AND SUSTENANCE OF DEMOCRACY IN NIGERIA". Calabar: CATS Publishers.

[9] Ekong, P. (2009). "THE NATURE OF MASS POVERTY". London: Harvard University Press.

[10] Esu, H. (2000). "FARMERS IN RURAL AREAS THEIR LIMITATIONS". Jos: Chatong and Son's Publishers. 
[11] George, K. (2008). “PROBLEMS IN RURAL SOCIETIES - THE WAY FORWARD”. Enugu: Uche's Printing Press.

[12] Ijere, O. (2004). "THE POVERTY OF NATIONS: THE DILEMMA AT THE HEART OF AFRICA". London: British Academic Press.

[13] Iyewaran, P. (2006). "ANALYTICAL FRAMEWORK FOR POVERTY REDUCTION ISSUES ECONOMIC GROWTH VERSUS OTHER STRATEGIES”. In Poverty Alleviation in Nigeria. Ibadan: UCH Prints.

[14] Ndu, E. (2002). "POVERTY AND DEPENDENCY PROBLEM". Enugu: Fourth Dimension Publishing Co. Ltd.

[15] Obadan, U. (2008). "INVESTMENT-LED POVERTY-REDUCTION EMPLOYMENT (IPRE) INITIATIVE IN OBASANJO'S ADMINISTRATION". Calabar: Jerry Commercial Productions.

[16] Sancho, P. (2008). "PROBLEM IN THE DEFINITION AND MEASUREMENT OF POVERTY". London: Heinemann.

[17] Townsend, O. (2008). "THE CONCEPT OF POVERTY”. London: Heinemann Education Books.

[18] Todaro, B. (2002). "PERSPECTIVE ON RURAL POVERTY IN NIGERIA". Calabar: Ojie Publishers.

[19] Odu, E. N. and Agida, P. (2003). "PERSPECTIVE ON NIGERIAN POLITICAL ECONOMY IN NIGERIA". Calabar: Ojies Publishers.

[20] Ukoha, H. (2007). “NIGERIA'S NEGLECTED RURAL MAJORITY”. Ibadan: Oxford University Press.

[21] Umokeh, G. (2008). "SOME ISSUES IN THE CONCEPTUALIZATION AND THEORY OF URBAN POVERTY IN NIGERIA". Lagos: Pearsons Printing Press.

[22] Uniamekogbu, O. (2005). "PROBLEMS ASSOCIATED TO RURAL FARMERS IN NIGERIA". Ile-Ife: University of Ife Press.

[23] Udo, V. (2009). "POVERTY AMONG RURAL DWELLERS IN THE $21^{\text {ST }}$ CENTURY". Uyo: Legacy Publishers.

[24] Ushie, G. (2009). "POVERTY AMONG FARMERS IN NIGERIA". Calabar: Rapid Education Publishers.

[25] Quartery, O. (2005). "POVERTY ALLEVIATION PROGRAMMES IN NIGERIA AND WHY IT FAILED”. Nsukka: Restoration Publishers.

[26] Wallace, R. and Wolt, A. (1980). "CONTEMPORARY SOCIOLOGICAL THEORY”. U.S.A: Prentice Hall Inc.

*Corresponding author.

E-mail address: rieneji@ yahoo.co.uk 